\title{
The Durand Line: Official Positions of Pakistan and Afghanistan over the Legitimacy of the Border
}

\author{
Tatiana Ponka \\ Department of theory and history of international relations \\ Peoples' Friendship University of Russia \\ Moscow, Russia \\ E-mail: ponka-rudn@mail.ru
}

\author{
Prashanta Dkhar \\ Department of Architecture and Civil Engineering \\ Peoples' Friendship University of Russia \\ Moscow, Russia \\ E-mail: dkhar.prashanta@gmail.com
}

\author{
Anita Dkhar \\ Department of Theory and History of International \\ Relations \\ Peoples' Friendship University of Russia \\ Moscow, Russia \\ E-mail: ann_dhar@mail.ru
}

\begin{abstract}
In the article authors analyze the historical background of the Durand Line, consider the influence of the unsolved border issue between Afghanistan and Pakistan on the bilateral relations and reveal features of a separated nation Pashtu`s nationalistic movement development.
\end{abstract}

Keywords-Durand Line; Pakistan; Afghanistan; Pashtu; Balochi; borders; separatism sentiments

\section{INTRODUCTION}

The border issue has always been a topical one in international relations. Borders has always been the main political institute essential for the economic, social and political life in developed societies" [1]. The constant intention to spread state borders was simultaneously forming different shapes of the world map. International society underwent the most significant changes during the colonial and postcolonial period and it mainly concerned the AfroAsian part of the globe. The African continent reminds of a smoothly drawn map of former European dominions. The established borders still exist and cause pressing problems to the majority of the regional countries of the continent. The South China Sea dispute has become a huge geopolitical resistance arena. South Asia has been facing a long-standing territorial conflict between India and Pakistan concerning Kashmir as well as Pakistan and Afghanistan concerning the borders [2].

The current borders formed in the XX century are based on international agreements of the Potsdam Conference following the Second World War conclusion. The agreements entrenched the peace principles, determined borders of the majority of the European countries and outlined the plan on the further border system development [3].
The border issue led to the separation of peoples. Thereafter, the people undergone such hardships formed into a factor of the international instability. Ossetians, Lezgians, Kurds etc. - all are considered to be the ethnic groups separated by the border issue. The most painfully the border separation regards to such groups as Kurds and Pashtuns whish were crucially fighting for the rights for identical and cultural independence during the last two centuries.

The article is devoted to the problem of the Durand Line, which serves as an interstate border between Afghanistan and Pakistan since the partition of the British India.

The main goal of the article is to reveal the motives of the British government while establishing the Durand Line, positions of Afghanistan and Pakistan over the border issue from the moment of partition of British Raj up to current developments.

As for the research objectives, these include the analysis of the evolution of the approaches of Afghanistan and Pakistan to the border issue as well as the review of the influence of the given issue on the regional processes.

The Afghanistan-Pakistan border issue (Durand Line) has been studied by both Russian and foreign scholars. The Russian group might be represented by the researches of $Y$. V. Gankovsky, V. Y. Belokrenitsky, V. B. Kravtsov, M. F. Slinkin, N. A. Khalfin. The authors objectively analyze the given issue, touching upon historical facts that makes it possible to examine and consider the actors' actions of that period and make certain conclusions.

Positions of the Afghani and Pashtun sides are demonstrated in a united group of scholars such as Said Qasim Reshtia, Afrosiab Khattak, Hazrat Bahar, Ghafoor Liwal. 
The Pakistani and south-asian researches are also represented by Madiha Afzal, Arka Biswas, Arwin Rahi, Shamshad Ahmad. Opinions of Pakistani scholars in some cases are different which can be explained by the difference of the Research Centers. Thus, Madiha Afzal is a representative of the Brookings Institute; Arka Biswas is a scholar of the Institute for Defense Studies and Analyses, while Shamshad Ahmad is a Pakistani former foreign minister who considers the Durand Line as a legal and internationally recognized border with Afghanistan.

Western scholars` group comprises such names as Lt. Arthur Conolly, Sir Percy Sykes, Leppel Griffin, Joseph V. Micallef. The first three scholars were directly executing the British policy in the Indian Dominion and Afghanistan in the XIX-XX centuries, thus, their writings are mainly of a descriptive memoir type.

\section{REGARDING THE QUESTION OF THE DURAND LINE ESTABLISHMENT}

Lt. Arthur Conolly, a British scout and writer of the XIX century, characterizes his century as an era of the -Great Game" [4], when Afghanistan was an object of competition between Russian Empire and British Crown as well as Napoleon France in alliance with Iran. Afghanistan was considered as a key to India, the British source of power and welfare [5]. Thus, the destiny of Afghanistan fated the further world development of the XIX century.

At that period Russia was a very influential country in the region, in addition, Iran and France were striving to gain profit from the British India. In order to defend national interests in the region, British Government had to take all possible measures. The bid to create allied relations with Afghanistan failed. As a result, through the use of political disputes within Afghanistan, its economic weakness and lack of diplomatic skills among Afghani officials, Britain intended to make Afghanistan dependent [6].

After the disastrous defeat in the first Anglo-Afghan War (1838-1842), Britain occupied Afghanistan in the course of the second Anglo-Afghan War in 1878. Afghanistan was transferred under the protectorate of British India according to the Treaty of Gandamak in 1879 [7] that led to the loss of territories of the Khyber Pass and others [7].

In 1880-s a new emir of Afghanistan Abdurrahman Khan demanded clarification of borders with the British India. In the circumstance when emir was letting the British control the foreign policy of his state in exchange for the sovereignty of the internal policy, the possibility to gain imperialistic plans for the British was obvious. In order to prevent Russian influence in the region, the British India was the first to initiate the demarcation of the Northern border of Afghanistan in 1887 that led to the Durand Line Agreement [8].

The Durand Line was established after the treaty signing between the emir of Afghanistan Abdurrahman Khan and foreign secretary of the English Colonial Administration of British India Sir Mortimer Durand in Kabul on the $12^{\text {th }}$ of November in 1893 [9]. The Line delineated the Southern,
Southwestern and Western borders of Afghanistan. The Agreement provided border establishment from the Karakorum valley on the North-West to the South through the Spin Ghar Mountains and to the West through the Chagai highland closely to Iran [10]. According to the Agreement, Kafiristan, Asman, Lyalioora and a part of Waziristan were finally added to Afghanistan, while emir Abdurrahman had to abandon the railway station New-Chanan as well as another part of Wasiristan, Kuram, Bajaur, Dira, Chitral, Afridistan etc. The subsidizing to emir was also enlarged from 12 to 18 lacks [11].

Leppel Griffin who was participating in the negotiations with A. Khan wrote 13 years later that Afghanistan was the most important part of the Indian Empire, so they could not let them stay locked-up. Firstly, he pointed out the necessity for the British minister - resident of access to Kabul with officers serving as agents in Kandahar and Herat. Secondly, it was essential to demand the railway prolongation between Kabul, Herat and British India. Finally - it was the elimination of all restrictive fees on English goods [12].

The significance of the Durand Line implied the separation of Pashtuns ' territory, which let the British control the mountain pass leading to Afghanistan. Officially, the British were striving for the bilateral relations' normalization and stabilization of the internal situation in Afghanistan. It is noteworthy that in case of any rejection from the Afghani side, the British threatened to wage war without leaving any choice to emir.

The Durand Line became the main premise of tensions between Afghanistan and British India as Afghani emirs never recognized the legitimacy of the Line. However, under the pressure of Britain they had to renew the border agreement maintaining the Durand Line existence. Abdurrahman Khan after the agreement signing attempted to cancel it by sending numerous letters about the invalidity of the Durand Line Agreement [6].

The Durand Line separated Pashtuns that informally belong to the territory of Pashtunistan. Pashtuns are warrior people speaking different dialects and following the Code of Honor Pashtunwali" [13]. This unique ethnic group managed to preserve its long-standing traditions and social system even being separated because of the strong-willed bellicose nature.

Therefore, the Durand Line establishment made the majority of the Pashtun people shift under the jurisdiction of the British India, while the other part left in Afghanistan. Afghanistan lost Baluchistan province and the historical access to the Arabian Sea and Indian Ocean, which made the country landlocked [14].

\section{THE DURAND LINE INFLUENCE ON THE MODERN RELATIONS BETWEEN PAKISTAN AND AFGHANISTAN}

In 1947 after the British India partition, modern India and Pakistan were established. The border dispute shifted to the Afghanistan-Pakistan relations and became a primer point in the bilateral relations [15]. 
In the very first years after Pakistan was established, Afghanistan stood against the recognition of the Durand Line [16]. In September 1947 Afghanistan also voted against Pakistan`s joining the UN [17] protesting against recognition of Pakistan`s borders. On 26 July 1948, the Government of Afghanistan officially nullified all the imposed" AngloAfghan border treaties [14].

Hereinafter Afghani officials were actively supporting the idea of the Independent Pashtunistan [18]. A former minister of Education M. Najubullah Khan on 4 February 1948 reported from the Kabul Radio station that the interests of Pashtuns were not counted in the process of partition and that they support their brothers` strivings towards their rights [19].

According to the Afghani scholars represented by Hazrat Bahar, the Durand Line Agreement had a term of 100 years. Such a fact comes out of an allegedly existing Afghan version of the Agreement written in Pashtu and Dari languages. This version stated that after 100 years all the territories would be returned to Afghanistan, however the given point was intentionally missed by M. Durand while creating the English version of the Agreement [8] and thus made it permanent. The majority of scholars, however, supports the idea that there has always been only the English version of the Agreement without any terms [9].

Speaking about the Pakistani elite's position over the Durand Line issue, the former foreign minister of Pakistan (1997-2000) Shamshad Ahmad in the «Pakistan and world affairs» stated that the Agreement established the border between India and Afghanistan, and it was internationally recognized after the partition in 1947 when Pakistan and India got independence[20]. According to the Pakistani Foreign Ministry Press Secretary Moazzam Khan, in the view of Pakistan, the Durand Line issue is settled [21].

The Durand Line plays an essential part for Pakistan as it provides more than $60 \%$ of Pakistan`s territory and serves as a factor of the country`s integrity [22]. In order to soften nationalistic sentiments within Pashtuns, Pakistani Government started implementing special actions directed to the unification of the Pakistani nation. From the 1970-s any mention of national diversity or historical uniqueness was superficial. Madiha Afzal, a scholar of the Brooking Institute, exemplifies this fact by a legendary hero of Pashtuns Bacha Khan, who was protesting against the partition of India in 1930-1940-s being a member of the Indian National Congress. After 1947, he claimed concerning his commitment to Pakistan, however Bacha Khan was still considered as an enemy to Pakistani Government and it is hardly can be found anything about Khan in information sources in Pakistan. According to Afzal, such an attitude was mainly caused by his Pashtun identity [23].

In general, Pakistani government makes huge investments to the Khyber Pakhtunkhwa province in order to create a stable development of the whole country. V.B. Kravtsov, a soviet scholar, considers such generosity as a fear to experience another territorial loss after the separation of the West Pakistan that led to the independence of
Bangladesh in 1971. Therefore, investments is the only effective way to maintain Pakistani integrity [24].

V.Y. Belokrenitsky, a famous Russian scholar, considers that the entanglement of the regional and bilateral balance of power does not let predict the Durand Line issue development. It is likely to maintain being a legal issue for a long time more. As for the real border, it mostly depends on the general situation in Afghanistan and Pakistan [25].

\section{CONCLUSION}

Polarized stances over the Durand Line make the bilateral relations between Afghanistan and Pakistan deteriorate. Relying on the current situation, it would be logical to conclude that till Afghanistan does not recognize the Durand Line, Pakistan will continue using different instruments in order to maintain its integrity, for example by influencing anti-afghan groupings, which leads to the instability in the whole region.

Many of Afghans, mainly Pashtuns, still harbor expectations that one day it will be possible to get back to their ancestral land. However, the idea seems unrealistic as Afghanistan in comparison with the Pakistan`s war, economic and political capabilities is much weaker. In addition, the 30 million Pashtun population does not demonstrate any strong desire to join 15 million brothers in Afghanistan.

Over 50 years Pashtuns have played significant role in civil and military activities of Pakistan holding prestigious offices. Nowadays personal interests prevail the ethnic ones, in this regard, the majority of Pashtuns would be for the Pakistani side.

As for the Afghans, a soviet scholar V. Basov states that they firstly have to draw attention to the internal situation and harmonize the multinational society of Pashtuns, Tajiks, Uzbeks, Hazaras, Kalasha etc. [24].

Nowadays the idea that interstate borders in the globalizing world do not play the prevailing role in international relations anymore is extremely popular with many scholars. Thus, the cultural and ethnic mix and extinction of national states is becoming a usual phenomenon reflecting globalization process $[26,27]$. In this regard, a famous Afghani scholar Ghafoor Liwal considers that the border issue settlement is not in the hands of the governments but Pashtuns [28]. He also recommends to strengthen interaction within the frameworks of South Asian Association of Regional Cooperation (SAARC) and calls for being more attentive in case of cultural identity of Pashtuns as it may help to work on the given problem more accurate [28].

A clearly established border may become a key factor to the regional security: there would be more ways to control the illegal trade and the migrant flow, and what is more - it may prevent intrusions of Taliban groupings. Peoples would live in peace developing their countries and building a stable future for the new generations through the cooperation and mutual understanding. 


\section{REFERENCES}

[1] Majevich N. M., Borders in the modern worl: new features in the times of globalization. // Pskovsky regionologichesky Jurnal. - 2006. - №3. - P. 3-14

[2] Territotial issue in the Afro-Asian world: [collective monograph] / ed.: D. V. Streltsov. - M.: Aspect Press, 2013. - 321 p

[3] Report on the foreign ministers meeting. 27.06.1945// USSR at international conferences of the Great Fatherland War 1941-1945.: Collection of Documents. VI. Berlin Conference of the Allied Powers - USSR, USA and Great Britain (17 July - 2 August 1945) M.:Political Literature Publishing House, 1984.

[4] Lt. Arthur Conolly, Journey to the North of India through Russia, Persia and Afghanistan. London, Richard Bentley, 1834. Reprint: New Dehli, Laurier Books Ltd, Asian Educational Services, 2001.

[5] Khalfin N.A., Failure of the British aggression in Afghanistan (XIX — XX.). - M.: Social Economic Literature Publishing House, 1989r. P. 410 .

[6] Said Qasim Reshtia, Afghanistan in XIX century.: Foreign Literature Publishing House, Moscow, 1953. - P.62 -204.

[7] Treaty of Gandomak by Muhammad Jamil Hanifi. URL: http://www.khyber.org/history/treaties/gandamak.shtml.

[8] Hazrat Bahar, Durand Line: A legal perspective $\backslash$ The Afgan Tribune. 22.06.2016. URL: http://aftribune.com/durand-line-a-legalperspective/.

[9] Durand Line agreement, 12.11.1893. Электронный pecypc: http://www.satp.org/satporgtp/countries/pakistan/document/papers/du randlineagrrement.htm.

[10] Spin Ghar Range // Encyclopedia Britannica. Электронный ресурс: https://global.britannica.com/place/Spin-Ghar-Range.

[11] Brig.-Gen. Sir Percy Sykes, A History of Afghanistan Vol. II". London: MacMillan \& Co. pp.182-188.

[12] Leppel Griffin, The Amir of Afghanistan, The Fortnightly Review", 1893, January.

[13] Abdul Raheem, Major Ethic groups in Pakistan // Ethnicity in Pakistan. URL: http://ethnicityinpakistan.blogspot.ru/.

[14] Joseph V. Micallef, Afghanistan and Pakistan: the poisoned legacy of the Durand Line. URL: http://www.huffingtonpost.com/joseph-vmicallef/afghanistan-and-pakistan b 8590918.html.

[15] Fenenko A., Conflict heritage of Durand // Afganistan.ru. 12.07.2015. URL: http://afghanistan.ru/doc/87407.html.

[16] UN voting. Admission of Yemen and Pakistan to membership in the United Nations : resolution / adopted by the General Assembly URL: http://unbisnet.un.org:8080/ipac20/ipac.jsp?session=148740A728Y1J $.9592 \&$ profile $=$ voting \&uri $=$ full $=3100023 \sim$ !909513 !1\&ri=1\&aspect $=$ power \&menu $=$ search $\&$ source $=\sim$ !horizon.

[17] UN Resolution 108 (II). 30.09.1947. URL: https://documents-ddsny.un.org/doc/RESOLUTION/GEN/NR0/039/69/IMG/NR003969.pd f.

[18] Volkov V. and Kurin M., Pushtunistan // Collection of documents, 1947-1959. - P. 292

[19] Najibullah Khan Statement. 04.02.48 // Collection of documents, 1947-1959 - P.45

[20] Shamshad Ahmad, Pakistan and World Affairs // Criterion quarterly. 25.01.14. URL: http://www.criterion-quarterly.com/pakistan-andworld-affairs/.

[21] Arwin Rahi, Why the Durand Line matters // The Diplomat. 21.02.2014. URL: http://thediplomat.com/2014/02/why-the-durandline-matters/.

[22] Durand line issue settled and closed. 25.10.2012. //URL: http://www.dawn.com/news/759397.

[23] Madiha Afzal, Identity goes beyond Islam in Pakistan // Foreign $\begin{array}{llll}\text { Policy. } & \text { February } 2016 . & \text { URL: }\end{array}$ http://foreignpolicy.com/2016/02/02/identity-goes-beyond-islam-inpakistan/.
[24] Kravtsov V. B., The life given to Afghanistan. 29.10.16. // Political Education. URL: http://lawinrussia.ru/content/zhizn-otdannayaafganistanu.

[25] Belokrenitsky V., Durand Line // Territotial issue in the Afro-Asian world. MGIMO. M.: Aspect Press, 2013, p. 230 - 233.

[26] Glick Schiller, A new analytic Framework for understanding migration // Toward a transnational perspective on migration Race, class, ethnicity and nationalism reconsidered // The New York Academy of Science, New York, P. 1-24.

[27] Julian V. Minghi, From conflict to harmony in border landscapes // The geography of border landscapes, London\&New York, Routledge, 1991.

[28] A. Ghafoor Liwal - Areas between Afghanistan and Pakistan and the present turmoil. URL: ac.jp/publictn/eurasia_border_review/no1/07_Liwal.pdf. 